\title{
NOVEL APPROACH FOR DETERMINATION OF BINDING CONSTANT AND THERMODYNAMIC ACTIVITY OF LIPOPHILIC DRUGS IN INCLUSION COMPLEXES
}

Dalia S. Shaker

Department of Pharmaceutics, Helwan University, Cairo, Egypt

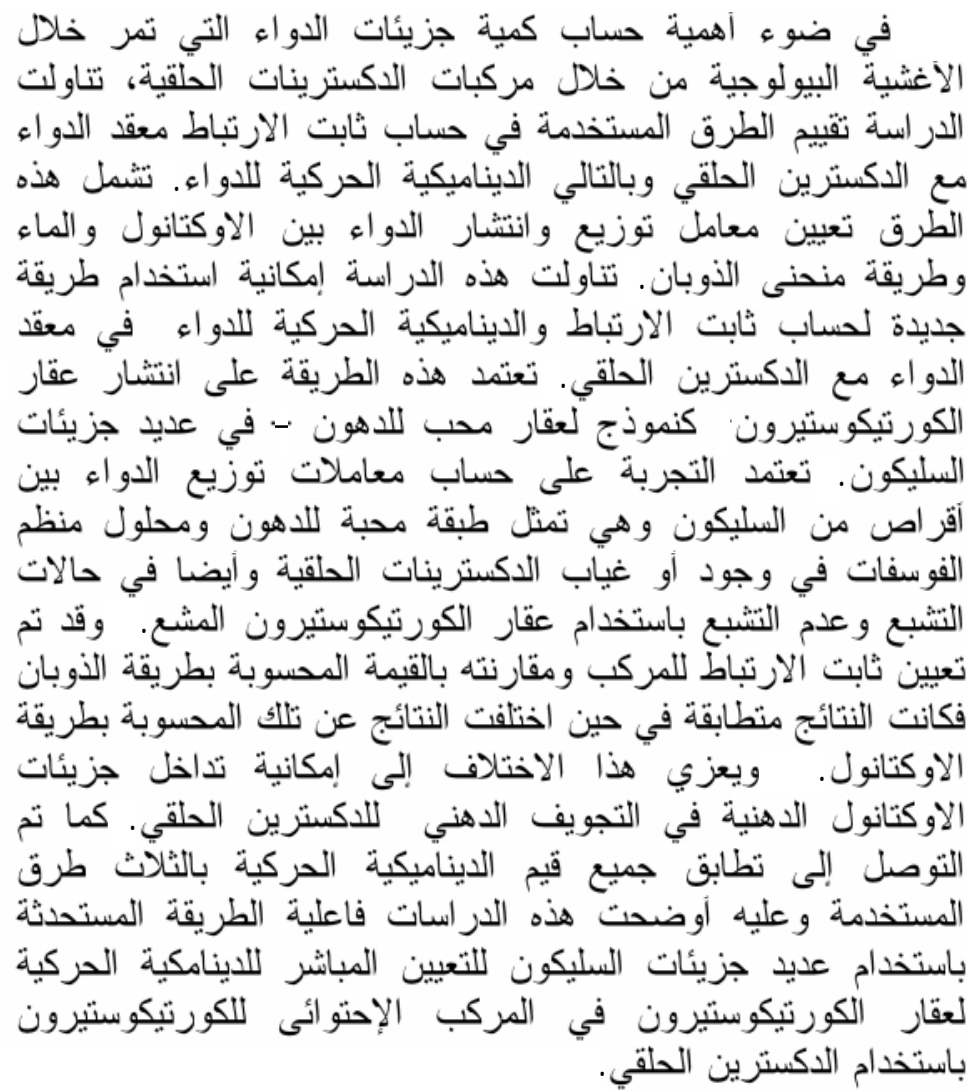

In light of prediction of extent of drug molecules that cross biological membranes in drug-complex system, there is a need to re-evaluate the old concept of measuring the binding constant of complexation $(\mathrm{Kc})$ and consequently the drug thermodynamic

Received in 12/11/2005 \& Accepted in 9/2/2006

Corresponding author E-Mail address: dalias_shaker@hotmail.com 
activity $\left(A_{T}\right)$ through octanol-water partition experiment or solubility technique at saturation condition. This study examined the feasibility of the silicone polymer uptake method for determination of $A_{T}$ of corticosterone (CS)-as a model lipophilic drug-in hydroxypropyl beta cyclodextrin (HPBCD). Commercial medical grade silicone rubber sheets were used first in the study then replaced by prepared silicone discs to ensure the validity of CS partition data obtained in silicone/phosphate buffered saline $(P B S)$ system in absence and presence of HPBCD. In cases of saturation and unsaturation with trace level radioactive corticosterone $\left({ }^{3} \mathrm{H}-\mathrm{CS}\right)$, the Kc was measured. It was the same at saturation as well as lower drug concentration, and in correlation with that measured by solubility technique at saturation. However, the Kc measured by silicone method deviated from that obtained from octanol/ phosphate buffered saline partition experiment due to possible interaction between HP $\beta C D$ as a complexing agent with lipophilic cavity and the organic phase (octanol). The measured $A_{T}$ values were in agreement with those determined by octanol and solubility methods. This study has clearly shown the validity of the silicone polymer uptake method for the direct determination of CS thermodynamic activity in CS/ HP $\beta C D$ inclusion complex.

\section{INTRODUCTION}

Previous studies ${ }^{1 \& 2}$ on transdermal permeation demonstrated that the stratum corneum (SC) lipid lamellae are well represented by octanol/water system. In these studies the correlation between steroids partitioning into lipid bilayer of Hairless Mouse Skin SC and their octanol/water partition coefficients was investigated in presence of chemical permeation enhancers. The data were consistent with the view that the enhancer polar head groups locate in the polar regions of SC lipid lamellae that are represented by water saturated octanol system. In their saturated systems the drug thermodynamic activity was unity i.e., all permeant molecules in the aqueous enhancer solutions are free as there was no kind of interaction between permeant and enhancer molecules. If a complexing agent was introduced in the system it appears to lower the thermodynamic activity of the drug. ${ }^{3}$

In order to develop drug delivery systems providing variable drug delivery rates for steroids, complexing agents such as cyclodextrins can be used. Cyclodextrins are capable of forming inclusion complexes ${ }^{4}$ with drugs. These non-covalent inclusion complexes can have physical, chemical and biological properties that are different from those of either 
the parent drug or cyclodextrin. These complexes can improve the chemical stability and/or the aqueous solubility of drugs ${ }^{5-7}$.

It is important to realize that the kinetics of inclusion complex formation and dissociation between a cyclodextrin and a drug molecule is fast. The half-lives for complex formation, dissociation are much less than one second. That is, inclusion complexation is dynamic process. ${ }^{8}$

The thermodynamic activity or chemical potential of drugs in inclusion complexes is viewed as the principle parameter in drug permeation through biological membranes. In this study, the feasibility was examined of a novel silicone polymer-uptake method for the direct determination of corticosterone (as a model lipophilic drug) thermodynamic activity in 2hydroxy propyl- $\beta$-cyclodextrin. This silicone polymer was used as a reference phase for calculating the complexation-binding constant and consequently quantifying the free corticosterone concentration available to cross biological membranes with different complexing agent concentrations

\section{EXPERIMENTAL}

\section{Materials}

SILASTIC $\AA$, medical grade silicone rubber sheets, $0.4 \mathrm{~cm}$ thickness, Dow Corning Corporation, Medical Products, Midland, Michigan, USA. Dimethylsiloxane MED-6033, two-component silicone elastomers that blend at 1:1 ratio by weight (Nusil, Silicone Technology, Carpinterie, CA). [ $\left.\quad{ }^{3} \mathrm{H}\right]$ Corticosterone $\left({ }^{3} \mathrm{H}-\mathrm{CS}\right)$ at $>95 \%$ purity was purchased from American Radiolabeled Chemicals, Inc. (St. Louis, MO) and tested for purity by methods suggested by the supplier. Phosphate buffered saline (PBS) tablets, $\mathrm{pH} 7.4$, were obtained from Sigma Chemical Company (St. Louis, MO) and used as received. Nonradiolabeled corticosterone (CS) (Sigma Chemical Company) was recrystallized in absolute ethanol. Hydroxypropyl- $\beta$-cyclodextrin (HP $\beta C D ; M W \sim 1380$, MS = 0.6) was purchased from Sigma. Phenolphthalein standard solution 1 $\mathrm{mg} / \mathrm{ml}$ in ethanol (Sigma Diagnostics, St. Louis, MO).

\section{Equipment}

Liquid scintillation counter, Model 1900 TR (TRI-CARB ${ }^{\text {TM }}$ liquid scintillation analyzers) Packard Instrument Company, USA. HPLC system consisted of a Beckman pump, a HP 1050 series auto-sampler HPLC, with a variable wave lenghth UV absorbance detector and a $15 \mathrm{~cm} \mathrm{x}$ $4.6 \mathrm{~mm}$ Discovery ${ }^{\circledR}$ C 18 column, packing particle size $4.0-4.3 \mathrm{~mm}$ (Supelco, Bellefonte, PA). Gravity oven, STABIL-THERM ${ }^{\circledR}$, Model OV-12A, Illinois, USA. Autoclave, HIRAYAMA, Amerex Instruments Incorporation, Lafayette, California, USA. Mini hot plate, Model 210, VWR Scientific, Willard, Ohio, USA. Thermostatted water bath model YB521, American Scientific Products, 
McGaw Park, IL,USA. Liquid scintillation cocktail, Ultima Gold, high flash-point universal LSCcocktail, Packard, Meriden, CT., USA. Scintillation Vials, Kimble Glass Inc., Vineland, New Jersey, USA. A series of micro-pipettes, Eppendorf 2000, variable volume, Brinkmann, VWR Scientific Products, Willard, Ohio, USA.

\section{METHODOLOGY}

Determination of corticosterone
partition coefficient by Silastic ${ }^{\circledR}$
rubber sheets partitioning
experiments
Prior to experiment, the SILASTIC $\AA$ rubber sheets were rinsed with PBS. Exactly one gm of medical grade silicone polymer (cut into pieces of dimension $<2 \mathrm{~mm}$ ) was added to each vial containing $1 \mathrm{ml}$ of various $\mathrm{CS}$ concentration with or without ${ }^{3} \mathrm{H}-\mathrm{CS}$ added in PBS from trace levels to CS solubility $(0.23$ $\mathrm{mg} / \mathrm{ml}$ ). The vials were left for 1-6 days to equilibrate in a shaking water bath at $37^{\circ}$. There was no significant difference between the partitioning data determined in the experiments with 2 to 6 days. Therefore, all experiments were carried out by leaving the vials for 4 days at $37^{\circ}$. After equilibrium was attained, aliquots from the aqueous phase were withdrawn and analyzed for ${ }^{3} \mathrm{H}-\mathrm{CS}$ content by scintillation counter after dilution with $10 \mathrm{ml}$ scintillation cocktail and for nonradiolabeled CS content by HPLC. Methanol (HPLC grade) / Water ratio of 66:34 was used as the mobile phase at a flow rate of $1.0 \mathrm{ml} / \mathrm{min}$. The ${ }^{3} \mathrm{H}-\mathrm{CS}$ or $\mathrm{CS}$ content of the silicone pieces was also determined after double extraction with absolute ethanol. The distribution of ${ }^{3} \mathrm{H}-\mathrm{CS}$ as well as CS molecules between silicone and aqueous solution, described by the partition coefficient was determined.

Validation of partitioning experiments after ethanol pretreatment of silastic sheets

In order to validate the partition coefficient data obtained in the previous experiment, the silicone sheets were pretreated with different procedures regarding rinsing or boiling in ethanol. Then pretreated sheets were dried and cut into pieces for partition experiments.

\section{Pretreatment of Silastic sheets Rinsing procedure}

About $5 \mathrm{gm}$ silicone rubber (cut into pieces of dimensions less than 2 $\mathrm{mm}$ ) was rinsed with $15 \mathrm{ml}$ boiling $95 \%$ ethanol for $10 \mathrm{sec}$. Almost all ethanol is rejected using disposable glass pipette and replaced with another $15 \mathrm{ml}$ boiling alcohol for second rinse of about $10 \mathrm{sec}$. A third rinse with $20 \mathrm{ml}$ boiling ethanol for $10 \mathrm{sec}$ took place followed by three times rinse with boiling deionized water (about $15 \mathrm{ml}$ for $10 \mathrm{sec}$ each rinse) to remove any residual alcohol.

\section{Boiling procedure}

About $15 \mathrm{ml}$ boiling $95 \%$ ethanol was added to $5 \mathrm{gm}$ silicone rubber. The polymer was allowed to boil on hot plate for about $20 \mathrm{sec}$, then 
removed from heater and all ethanol was removed and replaced by $15 \mathrm{ml}$ boiling alcohol and again the polymer was allowed to boil for another 20 sec. This procedure was repeated for the third time with $20 \mathrm{ml}$ boiling ethanol for $20 \mathrm{sec}$. After removal of all ethanol, the polymer was rinsed three times with boiling deionized water (about $15 \mathrm{ml}$ for $20 \mathrm{sec}$ each rinse).

\section{Boiling procedure under drastic conditions}

Five grams polymer was allowed to boil in $95 \%$ ethanol on hot plate for about $15 \mathrm{~min}$ (ethanol was removed and replaced by $15 \mathrm{ml}$ boiling alcohol about 5 to 6 times till 15 min boiling time acheived), then all ethanol removed and the polymer was rinsed five times with boiling deionized water (about $15 \mathrm{ml}$ for $60 \mathrm{sec}$ each rinse).

\section{Drying of the silicone rubber}

On aluminium foil, the polymer was left to dry for $2 \mathrm{hr}$ in oven at $75^{\circ}$, then left on desk top at room temperature for 24-36 hr.

Partition experiments were carried out with the three differently pretreated polymer samples and CS partition coefficient was calculated in each case and compared to that obtained with non pretreated silastic sheets.

\section{Preparation of silicone polymer}

Sheets of silicone were prepared by mixing equal amounts of dimethylsiloxane elastomers under vacuum. The mixture was spread onto glass dishes and allowed to cure at $150^{\circ}$ for $10 \mathrm{~min}$ in autoclave then left at room temperature for $24 \mathrm{hr}$ prior to use. Discs of $7 \mathrm{~mm}$ diameter and 1 $\mathrm{mm}$ thickness were cut and weighed.

Detection of hydroxypropyl- $\beta$ cyclodextrin diffusivity in prepared silicone polymer

A colorimetric technique was used to detect the diffusivity of HP- $\beta-C D$ in silicone discs. Vials containing 2 discs each in equilibrium with $2 \mathrm{ml}$ $5 \%$ HP- $\beta$-CD solution in PBS, were left for 4 days. After that, the HP- $\beta$ $\mathrm{CD}$ content in aqueous phase was determined. The $2 \mathrm{ml}$ solution in each vial was prepared for analysis by adding $500 \mu \mathrm{L}$ of $1.0 \mathrm{M} \mathrm{Na}_{2} \mathrm{CO}_{3}$ solution, followed by $200 \mu \mathrm{L}$ of phenolphthalein standard solution. The volume was completed to $5 \mathrm{ml}$ with PBS. In the control assays the sample was replaced by an equal volume of PBS. The color intensity was immediately measured at $550 \mathrm{~nm}$ against the blank at $25^{\circ}$. The HP- $\beta$ $\mathrm{CD}$ concentration was calculated from a calibration curve made by using $1-2000 \mu \mathrm{L}$ of the HP- $\beta-\mathrm{CD}$ standard.

The prepared silicone polymer partitioning experiments with different cyclodextrin concentrations

The prepared silicone discs were placed in $2 \mathrm{ml}$ vials ( 2 discs per vial) and equilibrated with $1 \mathrm{ml}$ solutions of various $\mathrm{CS}$ concentrations with or without ${ }^{3} \mathrm{H}-\mathrm{CS}$ added in PBS from trace levels to CS solubility and with 
different concentrations of $\mathrm{HP} \beta C D$ present. The vials were left for 1-8 days to equilibrate in a shaker water bath at $37^{\circ}$. There was no significant difference between the partitioning data determined in the experiments with 2 to 8 days (data not shown). Therefore, all experiments were carried out by leaving the vials for 4 days at $37^{\circ}$. After equilibrium was attained, aliquots from the aqueous phase were withdrawn and analyzed for ${ }^{3} \mathrm{H}-\mathrm{CS}$ content by scintillation counter and for nonradiolabeled CS content by HPLC. The ${ }^{3} \mathrm{H}-\mathrm{CS}$ or CS content of the silicone discs was also determined after double extraction with absolute ethanol. The drugsilicone/ HP $\beta C D$ partition coefficient was determined and used to calculate the complexation binding constant. The stability constant of complexation was calculated for both $\mathrm{CS}$ and ${ }^{3} \mathrm{H}-\mathrm{CS}$ separately then compared with that obtained by ordinary solubility method.

\section{Determination of $\mathrm{CS} /$ cyclodextrin binding constant by solubility method}

Exactly $70 \mathrm{mg}$ of CS previously recrystallized using ethanol was added to $8 \mathrm{ml}$ of solutions of different concentrations of HP $\beta C D$ in PBS, in screw capped Pyrex culture tubes. The tubes were shaken for $96 \mathrm{hr}$ at $37^{\circ}$ in a thermostatted water bath. The tubes were then centrifuged for 15 $\mathrm{min}$ at $3500 \mathrm{rpm}, 1318 \mathrm{~g}$. The clear supernatant solution was filtered through Millipore ${ }^{\circledR}$ filter previously saturated with the CS solution, and analyzed for CS concentration by HPLC. A phase-solubility diagram is constructed by plotting the total molar concentration of CS on the y-axis and the total molar concentration of cyclodextrin added on the $\mathrm{x}$-axis. The stability constant $(\mathrm{Kc})$ of $\mathrm{CS} / \mathrm{HP} \beta \mathrm{CD}$ complexes was determined from the slope of phase-solubility diagram and the solubility of CS in PBS. The Kc value obtained by this method was compared to that obtained by the silicone uptake method in order to validate this new approach for determination of drugs thermodynamic activities in complexation.

\section{Determination of ${ }^{3} \mathrm{H}-\mathrm{CS} / \mathrm{cyclo}$ - dextrin binding constant by octanol/PBS partitioning method}

In $13 \mathrm{ml}$ screw capped vials, exactly $2 \mathrm{ml}$ of octanol was added to $2 \mathrm{ml}^{3} \mathrm{H}-\mathrm{CS}$ solution in PBS with and without 1 and 5\% HP $\beta C D$. The experiments were carried out by leaving the vials for 4 days at $37^{\circ}$. After equilibrium was attained, $10 \mu \mathrm{l}$ aliquots from the aqueous phase as well as octanol phase were withdrawn and analyzed for ${ }^{3} \mathrm{H}-\mathrm{CS}$ content by scintillation counter. The partition coefficient of the radiolabeled drug between octanol and PBS and between octanol and HP $\beta C D$ were determined and used for calculation of stability constant of the complexation $(\mathrm{Kc})$. The value of $\mathrm{Kc}$ obtained by octanol/PBS partition method was compared to those obtained by silicone uptake and solubility methods. 
Calculation of CS thermo-dynamic activity in $\mathrm{HP} \beta C D$ inclusion complex

The thermodynamic activity of CS in the HP $\beta C D$ inclusion complex at equilibrium was calculated from data obtained by silicone uptake method, solubility technique and octanol/PBS partition.

\section{RESULTS AND DISCUSSION}

\section{Determination of corticosterone partition coefficient in Silastic ${ }^{\circledR}$ rubber sheets /PBS system}

The partition coefficient $(\mathrm{K})$ of non-radiolabelled corticosterone (CS) as well as radiolabelled drug $\left({ }^{3} \mathrm{H}-\mathrm{CS}\right)$ was determined using organic/ aqueous system. The organic phase was represented by pieces of Silastic ${ }^{\circledR}$ rubber sheets rinsed with PBS prior to use. Silicone polymer was selected as an inert polymer for its great diffusivity for organic molecules.

In literature, thin 0.006-inch thickness polyethylene discs, named Sallee's discs, were used to measure monomer activities of fatty acids in micellar solutions. ${ }^{9}$ There are other reports on measuring oleic acid and cholesterol uptake using Sallee's discs. ${ }^{10}$ Details of equilibrium times and whether oleic acid and cholesterol interact in the polyethylene discs were not discussed by these investigators. However, the diffusivities for organic molecules in silicone polymer are two orders of magnitude greater than in polyethylene. ${ }^{11}$ Therefore, silicone polymer was used in this study as a suitable organic phase for corticosterone partition coefficient determinations. The distribution coefficient $\mathrm{K}$ of $\mathrm{CS}$ molecules between silicone and aqueous solution was determined according to eq. (1)

$$
\mathrm{K}=\frac{\mathrm{A}_{\mathrm{SP}, \mathrm{Eq}} / \mathrm{Wt}_{\mathrm{SP}}}{\mathrm{A}_{\mathrm{Aq}, \mathrm{Eq}} / \mathrm{Wt}_{\mathrm{Aq}}}
$$

Where $\mathrm{A}_{\mathrm{SP}, \mathrm{Eq}}$ and $\mathrm{A}_{\mathrm{Aq}, \mathrm{Eq}}$ are the molar amounts of $\mathrm{CS}$ in silicone and aqueous mediums at equilibrium respectively measured by HPLC. $\mathrm{Wt}_{\mathrm{SP}}$ and $\mathrm{Wt}_{\mathrm{Aq}}$ are the weight in grams of silicone pieces and aqueous solution. For ${ }^{3} \mathrm{H}-\mathrm{CS}$, the $\mathrm{K}$ can be calculated as follow:

$$
\mathrm{K}=\frac{\mathrm{dpm}_{\mathrm{SP}} / \mathrm{Wt}_{\mathrm{SP}}}{\mathrm{dpm}_{\mathrm{Aq}} / \mathrm{Wt}_{\mathrm{Aq}}}
$$

Where dpm ${ }_{\text {sp }}$ and dpm ${ }_{\mathrm{Aq}}$ are the total radioactivity count expressed by dpm (disintegration per minute) units in silicone and aqueous phases respectively.

The results in Table (1) show that the $\mathrm{k}$ value of $\mathrm{CS}$ in silicone/PBS system was $0.46 \pm 0.022$ while that of ${ }^{3} \mathrm{H}-\mathrm{CS}$ in the same system was around unity. This discrepancy in results was not expected, as trace level radioactive species represents the non radiolabelled drugs-behavior. ${ }^{12-15}$ Therefore, the partition experiments 
were repeated after ethanol pretreatment of silastic sheets. The results in Table (2) demonstrate that for CS partition in silicone, the $\mathrm{K}$ value was changing with polymer pretreatment. It was $0.513 \pm 0.032$ after rinsing the polymer with boiled ethanol for $10 \mathrm{sec}$ compared to $0.46 \pm$ 0.022 after rinsing with PBS (Table 1). Also, the data in Table (2) show that the $\mathrm{K}$ value increased to $0.709 \pm$ 0.019 and $0.865 \pm 0.003$ with boiling the polymer in ethanol for $20 \mathrm{sec}$ and $15 \mathrm{~min}$, respectively. These results show the silicone pretreatmentdependent changes in the uptake of CS by the silicone polymer. However, the ${ }^{3} \mathrm{H}$-CS uptake by silicone polymer was not affected by silicone pretreatment. The $\mathrm{K}$ value of ${ }^{3} \mathrm{H}-\mathrm{CS}$ was constant and remained close to unity in all experimental conditions (data not shown).

The reason of discrepancy with commercial silicone sheet (Silastic $®$ ) may be due to presence of silica filler, and this filler was partially or completely removed with pretreatment of the polymer with ethanol. Removing this kind of impurity increases CS diffusivity in the polymer and consequently affects the quality of data obtained in CS partitioning experiments. However, this filler has negligible effect on diffusivity of ${ }^{3} \mathrm{H}-\mathrm{CS}$ in polymer due to the very small amounts of radioactive drug in the experiment and accordingly the small amounts diffused in silicone. Therefore it was important to find a method that measure the diffusivity of drugs from trace level to saturation i.e., independent on drug concentration. Silicone discs were prepared in this study and were used to determine the binding constant of complexation between CS and HP $\beta C D$. The data in Table (3) showed the constant K obtained with different pretreatment conditions of prepared silicone discs. Also the $\mathrm{K}$ value of CS was the same as that of trace level. The results show the validity of prepared silicone discs to determine the partition coefficient of CS at saturation as well as unsaturation.

The prepared silicone polymer partitioning experiments with different cyclodextrin concentrations

The cyclodextrin diffusivity in the prepared silicone discs was measured and there was no measurable depletion of HP $\beta C D$ in the aqueous layer due to the uptake of HP $\beta C D$ into silicone within the sensitivity limit of the colorimetric assay. This result indicates that there is no interaction between the prepared silicone polymer and the cyclodextrin used in this study. The CS silicone/ HP $\beta C D$ partition coefficient $\left(K_{x}\right)$ in $\mathrm{X}$ cyclodextrin concentration was determined and used to calculate the complexation binding constant. 
Table 1: Partition coefficient values of corticosterone in silicone/PBS system after rinsing SILASTIC ${ }^{\circledR}$ sheets with PBS.

\begin{tabular}{|c|c|c|c|c|}
\hline \multicolumn{5}{|c|}{ Non radiolabelled corticosterone (CS) } \\
\hline $\begin{array}{c}\text { Concentration of } \\
\mathrm{CS} \text { in } 1 \mathrm{ml} \text { aqueous } \\
\text { phase }\left(\mathrm{C}_{\mathrm{aq}, \mathrm{Eq}}\right)^{\mathrm{a}} \text { in } \\
\mathrm{mg} / \mathrm{ml}\end{array}$ & $\begin{array}{c}\text { Amount of CS in } \\
\text { silicone polymer } \\
\left(\mathrm{A}_{\mathrm{sp}, \mathrm{Eq}}\right)\end{array}$ & $\begin{array}{l}\text { Weight of } \\
\text { silicone in } \\
\text { gms }\left(\mathrm{Wt}_{\mathrm{sp}}\right)\end{array}$ & $\begin{array}{l}\text { Concentration of } \\
\mathrm{CS} \text { in } 1 \text { gm silicone } \\
\left(\mathrm{C}_{\mathrm{sp}, \mathrm{Eq}}\right)^{\mathrm{b}} \text { in } \mathrm{mg} / \mathrm{gm}\end{array}$ & $\begin{array}{l}\text { Partition } \\
\text { coefficient } \\
(\mathrm{K})^{*}\end{array}$ \\
\hline $0.201 \pm 0.001$ & $0.01 \pm 0.002$ & $0.11 \pm 0.01$ & $0.092 \pm 0.001$ & $0.46 \pm 0.022$ \\
\hline \multicolumn{5}{|c|}{ Radiolabelled corticosterone $\left({ }^{3} \mathrm{H}-\mathrm{CS}\right)$} \\
\hline $\begin{array}{l}\text { Dpm count in } 1 \mathrm{ml} \\
\text { aqueous phase } \\
\text { calculated from } 10 \\
\mu \text { sample }\left(\mathrm{C}_{\mathrm{aq}, \mathrm{Eq}}\right)^{\mathrm{a}} \\
\text { in dpm } / \mathrm{ml}\end{array}$ & $\begin{array}{l}\text { Total dpm count } \\
\text { in silicone } \\
\text { polymer }\left(\mathrm{A}_{\mathrm{sp}, \mathrm{Eq}}\right) \\
\text { in } \mathrm{dpm}\end{array}$ & $\begin{array}{l}\text { Weight of } \\
\text { silicone in } \\
\text { gms }\left(\mathrm{Wt}_{\mathrm{sp}}\right)\end{array}$ & $\begin{array}{l}\text { Dpm count in } 1 \mathrm{gm} \\
\text { silicone } \\
\left(\mathrm{C}_{\mathrm{sp}, \mathrm{Eq}}\right)^{\mathrm{b}} \text { in } \mathrm{dpm} / \mathrm{gm}\end{array}$ & $\begin{array}{l}\text { Partition } \\
\text { coefficient } \\
(\mathrm{K})^{*}\end{array}$ \\
\hline $245061 * *$ & 38116.9 & 0.154 & 247512.33 & 1.01 \\
\hline $291137 * *$ & 47979.39 & 0.16 & 299871.2 & 1.03 \\
\hline $223444 * *$ & 221165.5 & 0.98 & 225679.1 & 1.01 \\
\hline
\end{tabular}

*K value was calculated by dividing b/a.

**Average dpm count of four samples, $10 \mu \mathrm{l}$ each, to reduce pipetting errors.

Table 2: Determination of partition coefficient of corticosterone (CS) in silicone/PBS system after ethanol treatment of SILASTIC ${ }^{\circledR}$ sheets.

\begin{tabular}{|c|c|c|c|c|}
\hline \multicolumn{5}{|c|}{ Rinsing SILASTIC ${ }^{\circledR}$ sheets with boiled ethanol for 10 seconds } \\
\hline $\begin{array}{c}\text { Concentration of } \\
\text { CS in } 1 \mathrm{ml} \text { aqueous } \\
\text { phase }\left(\mathrm{C}_{\mathrm{aq}, \mathrm{Eq}}\right)^{\mathrm{a}} \text { in } \\
\mathrm{mg} / \mathrm{ml}\end{array}$ & $\begin{array}{l}\text { Amount of CS in } \\
\text { silicone polymer } \\
\left(\mathrm{A}_{\mathrm{sp}, \mathrm{Eq}}\right)\end{array}$ & $\begin{array}{l}\text { Weight of } \\
\text { silicone in } \\
\text { gms }\left(\mathrm{Wt}_{\mathrm{sp}}\right)\end{array}$ & $\begin{array}{l}\text { Concentration of } \\
\mathrm{CS} \text { in } 1 \mathrm{gm} \\
\text { silicone } \\
\left(\mathrm{C}_{\mathrm{sp}, \mathrm{Eq}}\right)^{\mathrm{b}} \text { in } \mathrm{mg} / \mathrm{gm}\end{array}$ & $\begin{array}{l}\text { Partition } \\
\text { coefficient } \\
(\mathrm{K})^{*}\end{array}$ \\
\hline $0.2176 \pm 0.0024$ & $0.01233 \pm 0.0023$ & $0.109 \pm 0.018$ & $0.1116 \pm 0.0059$ & $0.513 \pm 0.032$ \\
\hline \multicolumn{5}{|c|}{ Boiling of SILASTIC ${ }^{\circledR}$ sheets with ethanol for 20 seconds } \\
\hline $\begin{array}{c}\text { Concentration of } \\
\mathrm{CS} \text { in } 1 \mathrm{ml} \text { aqueous } \\
\text { phase }\left(\mathrm{C}_{\mathrm{aq}, \mathrm{Eq}}\right)^{\mathrm{a}} \text { in } \\
\mathrm{mg} / \mathrm{ml}\end{array}$ & $\begin{array}{c}\text { Amount of CS in } \\
\text { silicone polymer } \\
\left(\mathrm{A}_{\mathrm{sp}, \mathrm{Eq}}\right)\end{array}$ & $\begin{array}{c}\text { Weight of } \\
\text { silicone in } \\
\text { gms }\left(\mathrm{Wt}_{\mathrm{sp}}\right)\end{array}$ & $\begin{array}{l}\text { Concentration of } \\
\mathrm{CS} \text { in } 1 \mathrm{gm} \\
\text { silicone } \\
\left(\mathrm{C}_{\mathrm{sp}, \mathrm{Eq}}\right)^{\mathrm{b}} \text { in } \mathrm{mg} / \mathrm{gm}\end{array}$ & $\begin{array}{c}\text { Partition } \\
\text { coefficient } \\
(\mathrm{K})^{*}\end{array}$ \\
\hline $0.2107 \pm 0.0005$ & $0.02 \pm 0.0008$ & $0.134 \pm 0.004$ & $0.149 \pm 0.039$ & $0.709 \pm 0.019$ \\
\hline \multicolumn{5}{|c|}{ Boiling of SILASTIC $\AA$ sheets with ethanol for 15 minutes } \\
\hline $\begin{array}{c}\text { Concentration of } \\
\text { CS in } 1 \mathrm{ml} \text { aqueous } \\
\text { phase }\left(\mathrm{C}_{\mathrm{aq}, \mathrm{Eq}}\right)^{\mathrm{a}} \text { in } \\
\mathrm{mg} / \mathrm{ml}\end{array}$ & $\begin{array}{c}\text { Amount of CS in } \\
\text { silicone polymer } \\
\left(\mathrm{A}_{\mathrm{sp}, \mathrm{Eq}}\right)\end{array}$ & $\begin{array}{l}\text { Weight of } \\
\text { silicone in } \\
\text { gms }\left(\mathrm{Wt}_{\mathrm{sp}}\right)\end{array}$ & $\begin{array}{l}\text { Concentration of } \\
\mathrm{CS} \text { in } 1 \mathrm{gm} \\
\text { silicone } \\
\left(\mathrm{C}_{\mathrm{sp}, \mathrm{Eq}}\right)^{\mathrm{b}} \text { in } \mathrm{mg} / \mathrm{gm}\end{array}$ & $\begin{array}{l}\text { Partition } \\
\text { coefficient } \\
(\mathrm{K})^{*}\end{array}$ \\
\hline $0.2086 \pm 0.0009$ & $0.0213 \pm 0.0023$ & $0.117 \pm 0.005$ & $0.181 \pm 0.0007$ & $0.868 \pm 0.003$ \\
\hline
\end{tabular}

* K value was calculated by dividing b/a. 
Table 3: Determination of partition coefficient of corticosterone (CS) in silicone/PBS system after ethanol treatment of prepared silicone elastomer.

\begin{tabular}{|c|c|c|c|c|}
\hline \multicolumn{5}{|c|}{ Rinsing the prepared silicone polymer with boiled ethanol for 10 seconds } \\
\hline $\begin{array}{c}\text { Concentration of } \\
\mathrm{CS} \text { in } 1 \mathrm{ml} \text { aqueous } \\
\text { phase }\left(\mathrm{C}_{\mathrm{aq}, \mathrm{Eq}}\right)^{\mathrm{a}} \text { in } \\
\mathrm{mg} / \mathrm{ml}\end{array}$ & $\begin{array}{c}\text { Amount of CS in } \\
\text { silicone polymer } \\
\left(\mathrm{A}_{\mathrm{sp}, \mathrm{Eq}}\right)\end{array}$ & $\begin{array}{c}\text { Weight of } \\
\text { silicone in gms } \\
\left(\mathrm{Wt}_{\mathrm{sp}}\right)\end{array}$ & $\begin{array}{l}\text { Concentration of } \\
\mathrm{CS} \text { in } 1 \mathrm{gm} \text { silicone } \\
\left(\mathrm{C}_{\mathrm{sp}, \mathrm{Eq}}\right)^{\mathrm{b}} \text { in } \mathrm{mg} / \mathrm{gm}\end{array}$ & $\begin{array}{l}\text { Partition } \\
\text { coefficient } \\
(\mathrm{K})^{*}\end{array}$ \\
\hline $0.206 \pm 0.005$ & $0.0237 \pm 0.0051$ & $0.109 \pm 0.016$ & $0.216 \pm 0.013$ & $1.05 \pm 0.09$ \\
\hline \multicolumn{5}{|c|}{ Boiling of the prepared silicone polymer with ethanol for 20 seconds } \\
\hline $\begin{array}{c}\text { Concentration of } \\
\text { CS in } 1 \mathrm{ml} \text { aqueous } \\
\text { phase }\left(\mathrm{C}_{\mathrm{aq}, \mathrm{Eq}}\right)^{\mathrm{a}} \text { in } \\
\mathrm{mg} / \mathrm{ml}\end{array}$ & $\begin{array}{c}\text { Amount of CS in } \\
\text { silicone polymer } \\
\left(\mathrm{A}_{\mathrm{sp}, \mathrm{Eq}}\right)\end{array}$ & $\begin{array}{l}\text { Weight of } \\
\text { silicone in gms } \\
\left(\mathrm{Wt}_{\mathrm{sp}}\right)\end{array}$ & $\begin{array}{l}\text { Concentration of } \\
\mathrm{CS} \text { in } 1 \mathrm{gm} \text { silicone } \\
\left(\mathrm{C}_{\mathrm{sp}, \mathrm{Eq}}\right)^{\mathrm{b}} \text { in } \mathrm{mg} / \mathrm{gm}\end{array}$ & $\begin{array}{l}\text { Partition } \\
\text { coefficient } \\
(\mathrm{K})^{*}\end{array}$ \\
\hline $0.210 \pm 0.0005$ & $0.0197 \pm 0.0005$ & $0.097 \pm 0.0004$ & $0.202 \pm 0.004$ & $0.96 \pm 0.025$ \\
\hline \multicolumn{5}{|c|}{ Boiling of the prepared silicone polymer with ethanol for 15 minutes } \\
\hline $\begin{array}{c}\text { Concentration of } \\
\text { CS in } 1 \mathrm{ml} \text { aqueous } \\
\text { phase }\left(\mathrm{C}_{\mathrm{aq}, \mathrm{Eq}}\right)^{\mathrm{a}} \text { in } \\
\mathrm{mg} / \mathrm{ml}\end{array}$ & $\begin{array}{c}\text { Amount of CS in } \\
\text { silicone polymer } \\
\left(\mathrm{A}_{\mathrm{sp}, \mathrm{Eq}}\right)\end{array}$ & $\begin{array}{l}\text { Weight of } \\
\text { silicone in gms } \\
\left(\mathrm{Wt}_{\mathrm{sp}}\right)\end{array}$ & $\begin{array}{l}\text { Concentration of } \\
\mathrm{CS} \text { in } 1 \mathrm{gm} \text { silicone } \\
\left(\mathrm{C}_{\mathrm{sp}, \mathrm{Eq}}\right)^{\mathrm{b}} \text { in } \mathrm{mg} / \mathrm{gm}\end{array}$ & $\begin{array}{l}\text { Partition } \\
\text { coefficient } \\
(\mathrm{K})^{*}\end{array}$ \\
\hline $0.210 \pm 0.0002$ & $0.02 \pm 0.0003$ & $0.094 \pm 0.004$ & $0.213 \pm 0.01$ & $1.01 \pm 0.05$ \\
\hline
\end{tabular}

$* \mathrm{~K}$ value was calculated by dividing b/a.

$$
\mathrm{K}_{\mathrm{x}}=\frac{\mathrm{A}_{\mathrm{sp}} / \mathrm{wt}_{\mathrm{sp}}}{\mathrm{A}_{\mathrm{aq}, \text { total }} / \mathrm{wt}_{\mathrm{aq}}}
$$

Where $\mathrm{K}_{\mathrm{x}}$ is CS partition coefficient in Silicone/ HP $\beta C D$ system, $\mathrm{A}_{\mathrm{sp}}$ is the amount in moles of CS in the silicone elastomer. $\mathrm{A}_{\text {aq,total }}$ represents the total amount (in moles) of free CS plus solubilized or complexed $\mathrm{CS}$ in aqueous phase, $\mathrm{Wt}_{\mathrm{SP}}$ and $\mathrm{Wt}_{\mathrm{Aq}}$ are the weight in grams of silicone pieces and aqueous cyclodextrin solution. The $\mathrm{K}_{\mathrm{x}}$ value for radiolabelled drug obtained by measuring the radioactive count in both silicone and aqueous phases. After obtaining $\mathrm{K}$ and $\mathrm{K}_{\mathrm{x}}$ values, the stability constant of complexation was calculated for both $\mathrm{CS}$ and ${ }^{3} \mathrm{H}-\mathrm{CS}$ separately then compared with that obtained by ordinary solubility method.

\section{Determination of CS/cyclo-dextrin stability constant of complexation by silicone uptake method}

The CS/cyclodextrin stability constant of complexation $\mathrm{Kc}$ can be calculated from the measured concentration of total CS in cyclodextrin solution as well as the amount of CS in silicone polymer, using the equation: ${ }^{8}$

$$
\mathrm{K}_{\mathrm{C}}=\frac{\mathrm{S}_{\mathrm{t}}-\mathrm{S}_{0}}{\mathrm{~S}_{0}\left(\mathrm{~L}_{\mathrm{t}}-\left(\mathrm{S}_{\mathrm{t}}-\mathrm{S}_{0}\right)\right)}
$$

Where $S_{0}$ is the molar intrinsic CS solubility, $S_{t}$ is the total molar CS concentration in presence of total molar HP $\beta C D$ concentration $\left(\mathrm{L}_{\mathrm{t}}\right)$. 
This Kc value was later used for calculating the free CS concentration.

Determination of ${ }^{3} \mathrm{H}-\mathrm{CS} / \mathrm{cyclo}-$ dextrin stability constant of complexation by silicone uptake method

The ${ }^{3} \mathrm{H}-\mathrm{CS} /$ cyclodextrin stability constant of complexation $\mathrm{Kc}$ can be calculated from the equation:

$$
\mathrm{K}_{\mathrm{C}}=\frac{\left[\frac{\mathrm{K}}{\mathrm{K}_{\mathrm{x}}}-1\right]}{\mathrm{L}_{\mathrm{f}}}
$$

Where, $\mathrm{K}$ is ${ }^{3} \mathrm{H}-\mathrm{CS}$ partition coefficient in silicone/PBS system, $\mathrm{K}_{\mathrm{X}}$ is the ${ }^{3} \mathrm{H}-\mathrm{CS}$ partition coefficient in silicone/aqueous $\mathrm{HP} \beta \mathrm{CD}$ system, $\mathrm{Kc}$ (as in eq. 4) is the stability constant of the complex and $\mathrm{L}_{\mathrm{f}}$ is the free molar HP $\beta C D$ concentration in aqueous phase. For partitioning experiments in which only ${ }^{3} \mathrm{H}-\mathrm{CS}$ was used $\mathrm{L}_{\mathrm{f}} \approx \mathrm{L}_{\mathrm{t}}$.

\section{Calculation of the concentration of} free $\mathrm{CS}$ in cyclodextrin

The concentration of free CS in the cyclodextrin solution is determined from the following equation:

$$
\mathrm{C}_{\mathrm{aq}, \text { free }}=\frac{\mathrm{K}_{\mathrm{x}}}{\mathrm{K}} \mathrm{C}_{\mathrm{aq}, \text { total }}
$$

Where $\mathrm{C}_{\mathrm{aq}, \text { total }}$ was measured by HPLC during determination of $\mathrm{Kx}$ (eq. 3), also the $\mathrm{K}$ and $\mathrm{Kx}$ values were previously determined.
Calculation of the concentration of free ${ }^{3} \mathrm{H}-\mathrm{CS}$ in cyclodextrin

The Kc value obtained from eq (5) was used to calculate the free ${ }^{3} \mathrm{H}$ CS in cyclodextrin solution by the following equation:

$$
\begin{aligned}
& \text { Free[3H }-\mathrm{CS}], \mathrm{aq}= \\
& \frac{\text { Total }[3 \mathrm{H}-\mathrm{CS}], \mathrm{aq}}{\left[1+\mathrm{K}_{\mathrm{C}}\left(\mathrm{L}_{\mathrm{t}}\right)\right]}
\end{aligned}
$$

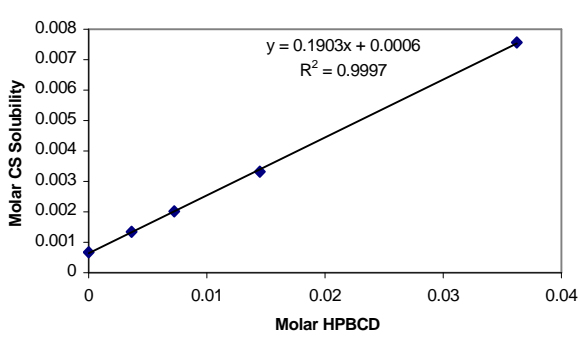

Fig. 1: Phase solubility diagram of corticosterone in $\mathrm{HP} \beta C D$ solution.

Determination of CS/cyclo-dextrin binding constant by solubility method

A phase-solubility diagram (Fig. 1) is constructed by plotting the total molar concentration of CS on the yaxis and the total molar concentration of cyclodextrin added on the x-axis. The stability constant $(\mathrm{Kc})$ of CScyclodextrin complexes was estimated from the slope of phasesolubility diagram and the solubility of CS in PBS (So). The stability constant was calculated according to equation (8): ${ }^{16}$ 


$$
\mathrm{K}_{\mathrm{C}}=\frac{\text { Slope }}{\mathrm{S}_{\mathrm{o}}(1-\text { Slope })}
$$

Where $S_{0}$ is the molar intrinsic drug solubility. In case of $A_{L}$-type diagram (linear diagram), the $\mathrm{Kc}$ was determined from the solubility data and used for calculating the free corticosterone concentration.

Table (4) shows the values of the complexation binding constant $(\mathrm{Kc})$ obtained at saturation and at trace levels in 1 and 5\% HPBCD with the silicone polymer partitioning method. The results show that all the data are consistent with a one-to-one complex governing the equilibrium behavior from trace levels to saturated solutions. Kc values calculated from the silicone partitioning method (357 to $369\left(\mathrm{M}^{-1}\right.$ ) are also consistent with the value obtained from the solubility data $\left(\sim 350(\mathrm{M})^{-1}\right)$. This shows the appropriateness of using a single binding constant $\left(\mathrm{Kc}=360(\mathrm{M})^{-1}\right)$ for the inclusion complex from trace levels of CS to saturation in calculating the free CS concentration.

\section{Determination of ${ }^{3} \mathrm{H}-\mathrm{CS} /$ cyclo- dextrin binding constant by octanol/PBS partitioning method}

The values of Kc obtained at trace levels in 1 and 5\% HP $\beta C D$ with the octanol/PBS partitioning method represented in Table (5). The results show that the $\mathrm{Kc}$ values calculated from this method (247 to 274) deviate from those obtained from both silicone uptake and solubility techniques. This result revealed that the old concept of organic/aqueous liquid phases i.e., octanol/water, partitioning becomes inadequate in describing drugs thermodynamic activity in complexes. In such partitioning experiments any complexing agent with a lipophilic cavity such as cyclodextrins, may interact with the liquid organic phase affecting the quality of partition data obtained.

\section{Calculation of CS thermodynamic activity in HPBCD inclusion complex}

The thermodynamic activity of $\mathrm{CS}, \mathrm{A}_{\mathrm{T}}$, in the HP $\beta C D$ inclusion complex at equilibrium was calculated from data obtained by silicone uptake method (data shown in Table 6), based on eq. (9): ${ }^{17}$

$$
\mathrm{A}_{\mathrm{T}}=\mathrm{C}_{\mathrm{sp}, \mathrm{Eq}} / \mathrm{C}_{\mathrm{sp}, \mathrm{Eq}}^{0}
$$

Where $\mathrm{C}^{0}$ is the $\mathrm{C}_{\mathrm{sp}, \mathrm{Eq}}$ value at corticosterone saturation. Equation (9) follows from the convention that a solution in equilibrium with corticosterone is at unit activity. The results revealed that CS thermodynamic activity in complex measured with silicone uptake method was 0.25 and 0.9 in 1 and 5\% HP $\beta C D$ solutions, respectively. These values were constant at saturation (Column 3 of Table 6) as well as at trace level of radiolabeled drug (Column 5 of Table 6).

In solubility experiments the $A_{T}$ was calculated from eq. (10) and demonstrated in Table (7). 


$$
\mathrm{A}_{\mathrm{T}}=\frac{1}{\mathrm{~F}}=\frac{1}{1+\frac{\mathrm{S}_{\mathrm{X}}}{\mathrm{S}_{\mathrm{O}}}}
$$

Where, $\mathrm{F}$ is a correction factor, $\mathrm{S}_{\mathrm{x}}$ and $\mathrm{S}_{\mathrm{o}}$ are the solubilities of nonradioactive $\mathrm{CS}$ in cyclodextrin and PBS, respectively. While $A_{T}$ was calculated from Octanol/ PBS partition coefficient by eq. (11) and the values have shown in Table (8).

$$
\mathrm{A}_{\mathrm{T}}=\frac{1}{\mathrm{~F}}=\frac{1}{1+\frac{\mathrm{K}_{\mathrm{X}}}{\mathrm{K}_{\mathrm{O}}}}
$$

Where $\mathrm{K}_{0}$ is the Octanol/ PBS partition coefficient of CS in absence of cyclodextrin while $K_{x}$ is the Octanol/ PBS partition coefficient of
$\mathrm{CS}$ at $\mathrm{x}$ cyclodextrin concentration. The results shows that the drug thermodynamic activity was constant for each cyclodextrin concentration, in all measuring methods revealing the validity of silicone polymer to measure lipophilic drugs thermodynamic activity. The discrepancy obtained in binding constant value measured by octanol/PBS partition method (Table 5) was due to interaction between cyclodextrin and octanol. However, this deviation in $\mathrm{Kc}$ was so small that it has no effect on CS- $\mathrm{A}_{\mathrm{T}}$ calculation (Table 8). May be this will not be the case with highly lipophilic drugs that have higher $\mathrm{Kc}$ values in cyclodextrins $(\mathrm{Kc} \geq 1000)$.

Table 4: Binding constant values determined from silicon uptake method that used to calculate the free corticosterone concentration in different

\begin{tabular}{|c|c|c|}
\hline Corticosterone Concentration & $\begin{array}{c}\text { Cyclodextrin } \\
\text { Concentration } \\
\% \mathrm{w} / \mathrm{v}\end{array}$ & $\begin{array}{c}\text { Binding Constant Kc } \\
\text { Calculated from Silicone/ PBS } \\
\text { Partition Coefficient }(\mathrm{M})^{-1}\end{array}$ \\
\hline \multirow{2}{*}{$\begin{array}{l}\text { Corticosterone saturated solution: } \\
0.23 \mathrm{mg} / \mathrm{ml}\end{array}$} & 1 & $373.4 * \pm 18(\mathrm{n}=9)$ \\
\hline & 5 & $367.8 * \pm 15(\mathrm{n}=8)$ \\
\hline \multirow{2}{*}{ Trace level corticosterone ${ }^{3} \mathrm{H}-\mathrm{CS}$} & 1 & $357.1 * * \pm 12(n>6)$ \\
\hline & 5 & $369.1 * * \pm 20(n>6)$ \\
\hline
\end{tabular}
cyclodextrin solutions.

*Kc values calculated by Eq. (4)

** Kc values calculated by Eq. (5)

${ }^{\mathrm{a}} \mathrm{Kc}$ determined from the solubility data and calculated by eq. (8) was $350(\mathrm{M})^{-1}$. 
Table 5: Octanol/ PBS partition coefficient and binding constants used to calculate the free ${ }^{3} \mathrm{H}-\mathrm{CS}$ concentration in different cyclodextrin solutions.

\begin{tabular}{|c|c|c|c|}
\hline $\begin{array}{c}\text { Cyclodextrin } \\
\text { Concentration } \\
(\% \mathrm{w} / \mathrm{v})\end{array}$ & $\begin{array}{c}{ }^{3} \mathrm{H}-\mathrm{CS} \text { Octanol/ } \\
\text { PBS Partition } \\
\text { Coefficient }\left(\mathrm{K}_{\mathrm{x}}\right)\end{array}$ & $\begin{array}{c}\text { Free Molar } \\
\text { Cyclodextrin } \\
\text { Conc. } \mathrm{L}_{\mathrm{f}}^{*}\end{array}$ & $\begin{array}{c}\text { Binding Constant Kc } \\
\text { Calculated from Octanol/ } \\
\text { PBS Partition } \\
\text { Coefficient**(M) }\end{array}$ \\
\hline 0 & $33.28 \pm 0.02(\mathrm{~K})$ & ------------ & ---------- \\
\hline 1 & $11.19 \pm 0.01$ & 0.0072 & $274.17(\mathrm{n}=5)$ \\
\hline 5 & $3.36 \pm 0.01$ & 0.036 & $247.35(\mathrm{n}=6)$ \\
\hline
\end{tabular}

* For ${ }^{3} \mathrm{H}$-CS partition experiments $\mathrm{L}_{\mathrm{f}} \cong$ the total molar cyclodextrin concentration.

** Determined by Eq. (5) and used to calculate the free radioactive CS in presence of cyclodextrin.

Table 6: Corticosterone (CS and ${ }^{3} \mathrm{H}-\mathrm{CS}$ ) thermodynamic activity values in $\mathrm{HP} \beta C D$ inclusion complex determined from silicon uptake method.

\begin{tabular}{|c|c|c|c|c||}
\hline $\begin{array}{c}\text { Cy- } \\
\text { Conc } \\
(\% \mathrm{w} / \mathrm{v})\end{array}$ & $\begin{array}{c}\text { Concentration of } \\
\mathrm{CS} \text { in 1 gm silicone } \\
\left(\mathrm{C}_{\mathrm{sp}, \mathrm{Eq}}\right) \text { in mg/gm }\end{array}$ & $\begin{array}{c}\text { CS thermo- } \\
\text { dynamic } \\
\text { activity* }\left(\mathrm{A}_{\mathrm{T}}\right)\end{array}$ & $\begin{array}{c}\text { Dpm count in } \\
1 \mathrm{gm} \text { silicone } \\
\left(\mathrm{C}_{\mathrm{sp}, \mathrm{Eq}}\right) \text { in dpm/gm }\end{array}$ & $\begin{array}{c}{ }^{3} \mathrm{H}-\mathrm{CS} \text { thermo- } \\
\text { dynamic } \\
\text { activity* }\left(\mathrm{A}_{\mathrm{T}}\right)\end{array}$ \\
\hline 0 & $\begin{array}{c}0.213 \pm 0.01 \\
\left(\mathrm{C}_{\mathrm{sp}, \mathrm{Eq})}^{0}\right.\end{array}$ & 1 & $\begin{array}{c}257687.5 \pm 38128 \\
\left(\mathrm{C}_{\mathrm{sp}, \mathrm{Eq})}^{0}\right.\end{array}$ & 1 \\
\hline 1 & $0.053 \pm 0.002$ & 0.248 & $64421.8 \pm 7782$ & 0.25 \\
\hline 5 & $0.019 \pm 0.000$ & 0.089 & $22934.2 \pm 2770$ & 0.089 \\
\hline
\end{tabular}

* Determined by Eq. (9).

Table 7: Corticosterone (CS) thermodynamic activity values in $\mathrm{HP} \beta C D$ inclusion complex determined from solubility technique.

\begin{tabular}{|c|c|c|c|}
\hline $\begin{array}{c}\text { Cyclodextrin } \\
\text { Concentration } \\
(\% \mathrm{w} / \mathrm{v})\end{array}$ & $\begin{array}{c}\text { CS solubility } \\
(\mathrm{mg} / \mathrm{ml})\end{array}$ & $\begin{array}{c}\text { Correction } \\
\text { factor } \mathrm{F}^{*}\end{array}$ & $\begin{array}{c}\mathrm{CS} \\
\text { thermodynamic } \\
\text { activity }\left(\mathrm{A}_{\mathrm{T}}\right)=1 / \mathrm{F}\end{array}$ \\
\hline 0 & $0.23 \pm 0.001\left(\mathrm{~S}_{0}\right)$ & ----------- & $1^{* *}$ \\
\hline 1 & $0.69 \pm 0.01$ & 4.0 & 0.25 \\
\hline 5 & $2.30 \pm 0.01$ & 11.2 & 0.089 \\
\hline
\end{tabular}

* Determined from Eq. (10)

** At saturation $\mathrm{A}_{\mathrm{T}}$ is unity. 
Table 8: Corticosterone (CS) thermodynamic activity values in HP $\beta C D$ inclusion complex determined from octanol/PBS partition.

\begin{tabular}{|c|c|c|c||}
\hline $\begin{array}{c}\text { Cyclodextrin } \\
\text { Concentration } \\
(\% \mathrm{w} / \mathrm{v})\end{array}$ & $\begin{array}{c}{ }^{3} \mathrm{H}-\mathrm{CS} \text { Octanol/ PBS } \\
\text { Partition Coefficient } \\
\left(\mathrm{K}_{\mathrm{x}}\right)\end{array}$ & $\begin{array}{c}\text { Correction } \\
\text { factor } \mathrm{F}^{*}\end{array}$ & $\begin{array}{c}\mathrm{CS} \text { thermodynamic } \\
\text { activity }\left(\mathrm{A}_{\mathrm{T}}\right)=1 / \mathrm{F}\end{array}$ \\
\hline 0 & $33.28 \pm 0.02(\mathrm{~K})$ & ------ & 1 \\
\hline 1 & $11.19 \pm 0.01$ & 3.97 & 0.25 \\
\hline 5 & $3.36 \pm 0.01$ & 10.9 & 0.091 \\
\hline
\end{tabular}

* Determined from Eq. (11).

\section{Conclusion}

The objective of this research is to investigate a direct method for calculation of free drug that affect permeability behavior with complexation. As revealed from the present study it can be concluded that; silicone uptake method is valid to calculate the binding constant of complexation $(\mathrm{Kc})$ at saturation as well as lower drug concentration represented by radiolabelled drug.

Silicone as lipophilic inert solid phase mimic the behavior represented by biological membranes or stratum corneum (SC) as the amount of drug partitioned in this polymer represent what will be actually partitioned in phospholipids bilayer of membranes and SC in presence or absence of complexing agents. In contrast to octanol/water liquid system in which a complexing agent with lipophilic cavity can interact with the organic phase (octanol) leading to result variation in partition coefficient data. In contrast to solubility technique that applied only at saturation and with $\mathrm{A}_{\mathrm{L}}$ solubility type.

\section{Acknowledgments}

These studies were financially supported by a grant-in-aid from NIH Grant GM43181. The author would like to thank Prof. Dr. William I. Higuchi and Prof. Dr. Abdel-Halim Ghanem for providing the necessary facilities.

\section{REFERENCES}

1- K. S. Warner, S. K. Li and W. I. Higuchi, J. Pharm. Sci., 90, 1143 (2001).

2- N. He, K. S. Warner, D. Chantasart, D. S. Shaker, W. I. Higuchi and S. K. Li, ibid., 93, 1415 (2004).

3- D. S. Shaker, A. H. Ghanem, S. K. Li, K. S. Warner, F. M. Hashem, and W. I. Higuchi, Int. J. Pharm., 253, 1 (2003).

4- T. Loftsson and M. Brewster, J. Pharm. Sci., 85, 1017 (1996).

5- R. A. Rajewski and V. J. Stella, ibid., 85, 1142 (1996).

6- D. Duchene and D. Wouessidjewe, Chimicaoggi, Jan./Feb., 17 (1993). 
7- V. J. Stella and R. A. Rajewski, J. Pharm. Res., 14, 556 (1997).

8- H. W. Frijlink, E. J. F. Franssen, A. C. Eissens, R. Oosting, C. F. Lerk and D. K. F. Meijer, ibid., 8, 380 (1991).

9- V. L. Sallee, Lipid Res., 5, 56 (1974).

10- K. Chijiiwa and W. G. Linscheer, Am. J. Physiol., 246, G492 (1984).

11- J. D. White and T. J. Bradley, J. Pharm. Sci., 62, 1634 (1973).

12- A-H. Ghanem, H. Mahmoud, W. I. Higuchi, U. Rohr, S. Borsadia, P. Liu, J. L. Fox and W. R. Good, J. Cont. Rel., 6, 75 (1987).
13- A-H. Ghanem, H. Mahmoud, W. I. Higuchi, P. Liu and W. R. Good, Int. J. Pharm., 78, 137 (1992).

14- Y. Kim, A-H. Ghanem, H. Mahmoud and W. I. Higuchi, ibid., 80, 17 (1992a).

15- Y. Kim, A-H. Ghanem and W. I. Higuchi, Seminars in Dermatology, 11, 145 (1992b).

16- T. Higuchi and K. A. Connors, Adv. Anal. Chem. Instrum., 4, 117 (1965).

17- H. Lee Paul, Daniel C. H. Cheng, Kozo Takayama and William I. Higuchi, J. Pharm. Sci., 77, 610 (1988). 